er did not improve the spermatozoa survival, it allowed to preserve the fertilizing ability one more day than with the $\mathrm{BL}_{1}$ extender. It could be used till the third day after collection since, in this case, the gestation rate was still 77 p. Ioo.

\title{
Effects of feeding maize contaminated by fusarium to sows
}

\author{
M. ÉTIENNE, M. JEMMAII \\ Station de Recherches sur l'Lílevage des Porcs, \\ Centre national de Recherches zootechniques, I.N.R.A., \\ 78350 Jouy-en-Josas (France) \\ Laboratoive de Technologie Alimentaive, Service des Mycotoxines, I.N.R.A., \\ I6, rue Nicolas-Fortin, 75013 Paris
}

An experiment involving 38 Large White gilts was undertaken in order to determine more accurately the effects of consumption of maize contaminated by Fusarium roseum, on reproduction. Females entered the experiment on puberty, were sired at the second oestrus and slaughtered after 80 days of pregnancy. They were divided into 3 groups receiving different feeds before and after mating: control feed without mycotoxins, or a contaminated one containing $3.6 \mathrm{I} \mathrm{mg}$ zearalenone $/ \mathrm{kg}$.

Ingestion of the contaminated feed by mature non pregnant gilts (2nd group) led to pseudopregnancy in more than half $(7 / 13)$ of the animals: the non return to ostrus for 45 days following puberty was confirmed by the absence of Corpora albicantia, maintaining of corpora lutea and uterus hypertrophy. These signs were also evident in 2 females of the $3^{\text {rd }}$ group which were not mated and which received the contaminated diet after service. The œstrogenic properties of zearalenone already demonstrated in immature animals was thus confirmed in mature gilts.

In comparison with the control group (Ist group), intake of maize contaminated by Fusarium roseum after service ( 3 rd group) did not affect corpora lutea weight, litter size $(8,9)$, embryonic mortality ( $32 \mathrm{p}$. IOO) or the number of abnormal fœetuses after 80 days of pregnancy. However the weight of uterine horns, placenta and foetuses decreased by 25,37 and $26 \mathrm{p}$. roo respectively.

Intake of zearalenone in breeding gilts principally led to a prolonged period of ancestrus and a decrease in the development of the concepta. This may explain some of the reproductive disorders reported after mouldy maize consumption by sows: lower fertility rate, abnormal œstrus returns, increase in the mortality of embryos and newborn piglets.

\section{Easy establishment of weaning batches for gilts owing to the use of a progestagen (RU 2267)}

\author{
Françoise MARTINAT-BOTTE (1), F. BARITEAU $\left({ }^{2}\right)$, \\ J.-P. SCHEID (3), J. GAUTIER (2), P. MAULEON (2) \\ (1) I.T.P., x49, vue de Bevcy, 75595 Paris Cedex I2 \\ (2) Station de physiologie de la Reproduction, \\ Centre de Recherches de Tours, I.N.R.A., \\ Nouzilly, 37380 Monnaie (France) \\ $\left.{ }^{3}\right)$ Département de Recherches Vétérinaires, \\ Roussel-Uclat, 35, bd des Invalides, 75323 Paris
}

Three hundred and thirty one 6 to 8 month old gilts were treated with a component possessing a progestational activity RU 2267. After the end of the treatment ( 8 days, per os, $20 \mathrm{mg}$ ) $\mathrm{d} /$ gilt) half of the batch was systematically inseminated on days 6 and 7 (in heat or not); the 
other animals were inseminated after return to heat 20 days post treatment (control group). Parallel to that, the effect of the number of spermatozoa per insemination was studied.

Three gilts out of four systematically inseminated on days 6 and 7 after the treatment were in oestrus according to the observations of the farmer. In the control group $6 \mathrm{p}$. I oo of the animals were not inseminated because they did not return to heat. The variability of the results was essentially due to differences between herds in the number of animals with delayed puberty. Like all progestagens, " RU 2267 " had only an effect on puberal gilts. On the other hand, grouping of oestruses was better when the gilts were fed individually.

This technique allows to control the cycles without detection of ostrus and to use A.I. on days fixed in advance. As a matter of fact, when the progestagen was distributed individually, the farrowing rate after systematic insemination with $12.0^{9}$ spermatozoa was 68.5 p. I 100 (9.8 piglets born alive on an average), a result similar to that of the controls $(58 \mathrm{p}$. I00; I0.3 piglets born alive). The fertility after induction of ostrus (percentages calculated from animals in heat at the moment of irisemination) was nearly $7^{\circ} \mathrm{p}$. I oo. However, better results were obtained after use of $12.10^{9}$ spermatozoa when the progestagen was given individually (farrowing rate: 87.2 p. Ioo; 9.8 piglets born alive on an average). A similar effect was not observed int the corresponding control group (farrowing rate: $67.5 \mathrm{p}$. I00; 10.3 piglets born alive on an average). The progestagens seem to have a depressive effect on survival and migration of spermatozoa in the female genital tract, as often observed in the other species.

\title{
Better control of post lactation oestrus by means of a progestagen (RU 2267)
}

\author{
Françoise MARTINAT-BOTTE $\left({ }^{1}\right)$, F. BARITEAU $\left({ }^{2}\right)$, J. GAUTIER $\left({ }^{2}\right)$, P. MAULÉON ( \\ (1) I.T.P., I49, rue de Bercy, 75595 Pavis Cedex I2 \\ (2) Station de physiologie de la Reproduction, \\ Centre de Recherches de Tours, I.N.R.A., \\ Nouzilly, 37380 Monnaie (France)
}

Suckling sows were given a component possessing a progestative activity RU 2267 for 7 days ( 3 days before drying off, the very same day, three days after). At the end of the treatment, sows were systematically inseminated on days 6 or 7 (in cestrus or not). The control females of the same age as the former ones were inseminated after the onset of cestrus (double artificial insemination at 24 hours interval). The effect of the number of spermatozoa per insemination was studied.

In the suckling sow, the progestagen RU 2267 at the dose of $30 \mathrm{mg} / \mathrm{sow} / \mathrm{day}$ had a depressive effect on the return to cestrus: II.5 p. I oo females were not in heat at the moment of systematic inseminations, versus I p. Ioo in the controls. This might be due to the progestagen concentration. Moreover, the fertility was very low: $53 \mathrm{p}$. I 100 farrowed 9.2 piglets on an average (a total of $\mathrm{I}+3$ sows). Higher fertility and prolificacy were noticed in the controls: $70.6 \mathrm{p}$. Ioo and ro.6 piglets (a difference of r.5 pigiets was observed between control and treated sows). On the contrary, when analysing these results relative to the number of spermatozoa employed for AI, a substantial improvement of the farrowing rate was noticed with $6.10^{9}$ spermatozoa/AI instead of $3.10^{9}$ and without any overfeeding after the end of the progestative treatment (76.2 versus 48.8 p. Ioo). Prolificacy remained always lower than that of the controls. 